now taking place throughout the world in spite of increasing urbanization. In cities in technically developed rich countries, malnutrition in infants and young children has been largely eliminated.

\title{
REFERENCES
}

Ashby, H. T. (I915). Infant Mortality. Cambridge: University Press.

Burnett, J. (1966). Plenty and Want. London: Nelson.

Dema, I. S. \& Den Hartog, A. P. (I 969). Urbanisation and Dietary Change in Tropical Africa. The Food and Nutrition Bulletin of the Joint FAO/WHO/OAU-STRC Regional Food and Nutrition Commission for Africa.

Newman, C. (1906). Infant Mortality. A Social Problem. London: Methuen \& Co.

\section{Food in nineteenth century England: nutrition in the first urban society}

\section{By D. J. Opdy, Department of Nutrition, Queen Elizabeth College, London, W8}

\section{Introduction}

When the English philosopher, Thomas Hobbes, described man's existence in the state of nature as 'solitary, poore, nasty, brutish, and short' (Hobbes, I 65 I) it seemed almost a description of the England of his own times. A pre-industrial society, like that of seventeenth and eighteenth century England, had very limited possibilities of economic production. Essentially it was tied to the level of agricultural output and reflected fluctuations in population growth, in prices, in foreign trade and levels of income. Also, while there was a lack of systematic understanding of the physical environment, there could be little marked advance in technology. Consequently, in such a society food production necessarily occupied a large part of the labour force and, although income levels were low, much of what was earned was spent not in investment in new techniques, but in spasmodic high living or in wars or in religious monuments---to the economist the parish churches and cathedrals of England represent the non-productive fixed capital of a past age.

\section{Industrialization and urbanization}

Although the traditional society's control over its resources was limited, the nutritionist has to recognize that its population survived and succeeded in reproducing itself, however irregular work and income might have been or whatever mishaps befell the harvest. What is more, there was a marked growth in population during the second half of the eighteenth century. In England in I $80 \mathrm{r}$ there were some $50 \%$ more people than in the mid-eighteenth century: estimates for $175^{\circ}$ suggest the population was about $6.5 \times 10^{6}$ persons, and $9.1 \times 10^{6}$ in $180 \mathrm{r}$. Whatever the reasons for this growth, it appears to be part of a European-wide movement (Cipolla, I965). Table $\mathrm{r}$ shows population growth in Britain during the nineteenth century. Between I 801 and 1911 , the decennial rate of increase was always in excess of $10 \%$. By 
Table I. Population growth in Great Britain, I78I-1931

\begin{tabular}{|c|c|c|c|}
\hline \multicolumn{4}{|c|}{ (Millions of people) } \\
\hline Year & Total & $\begin{array}{c}\text { Percentage } \\
\text { increase }\end{array}$ & Ireland \\
\hline I $78 \mathrm{I}$ & $8 \cdot 900$ & 一 & $4^{\circ} 100$ \\
\hline $\begin{array}{l}1791 \\
1801\end{array}$ & $\begin{array}{r}9.700 \\
10.686\end{array}$ & $\begin{array}{r}9 \cdot 0 \\
10.2\end{array}$ & $\begin{array}{l}4 \cdot 800 \\
5 \cdot 216\end{array}$ \\
\hline $\begin{array}{l}1811 \\
1821\end{array}$ & $\begin{array}{l}12 \cdot 147 \\
14 \cdot 206\end{array}$ & $\begin{array}{l}\text { I } 37 \\
16.0\end{array}$ & $\begin{array}{l}5 \cdot 956 \\
6 \cdot 802\end{array}$ \\
\hline 1831 & $16 \cdot 368$ & $15 \cdot 2$ & $7 \cdot 767$ \\
\hline $184 \mathrm{I}$ & I $8 \cdot 55 \mathrm{r}$ & 13.4 & $8 \cdot 200$ \\
\hline $185 \mathrm{I}$ & $20 \cdot 879$ & 12.5 & 6.514 \\
\hline I 86 I & $23 \cdot 189$ & I I I I & $5 \cdot 788$ \\
\hline 1871 & $26 \cdot 158$ & 2.7 & $5 \cdot 398$ \\
\hline I88 & $29 \cdot 789$ & 13.9 & $5+146$ \\
\hline 1891 & $33 \cdot 122$ & $I I \cdot 2$ & $4^{\cdot 680}$ \\
\hline I9OI & $37 \cdot 093$ & $12 \cdot 0$ & $4^{-4} 46$ \\
\hline rgIt & 40.918 & 10.3 & $4 \cdot 3^{81}$ \\
\hline I $92 \mathrm{I}$ & $42 \cdot 8 I 4$ & $4 \cdot 6$ & $4 \cdot 354$ \\
\hline I93 I & $44 \cdot 83 \mathrm{I}$ & $4 \cdot 7$ & $4 \cdot 176$ \\
\hline
\end{tabular}

From Deane \& Cole (1967). Irish figures include Eire for $192 \mathrm{r}$ and $\mathrm{r} 93 \mathrm{r}$.

contrast, Ireland shared in the population expansion until, in the absence of industrial progress, the 'potato famine' acted as a check to growth in the way common among pre-industrial societies. In Britain, however, the process of self-sustaining economic growth characteristic of an industrializing country was coeval with population growth. Table 2 illustrates the growth of the non-agricultural sector of the economy, and shows clearly the importance of the second quarter of the nineteenth century in establishing this trend.

Table 2. Index of industrial production in the United Kingdom (1913=100)

\begin{tabular}{|c|c|c|c|}
\hline Year & Index & Year & Index \\
\hline $180 \mathrm{I}$ & $5 \cdot 35$ & I $87 \mathrm{I}$ & $46 \cdot I$ \\
\hline I 8 I I & 7.03 & $188_{I}$ & $54 \cdot 6$ \\
\hline 1821 & $8 \cdot 47$ & 1891 & $65 \cdot 8$ \\
\hline $183 \mathrm{I}$ & I $2 \cdot 8$ & 1901 & $75 \cdot 8$ \\
\hline 1841 & $18 \cdot 1$ & I9II & $89 \cdot 6$ \\
\hline 1851 & 243 & & \\
\hline I 86I & $33 \cdot 6$ & & \\
\hline
\end{tabular}

From Mitchell \& Deane (I962) and Hoffman (I955).

Table 3. The growth of urban areas: internal migration in England, $184 \mathrm{I}-\mathrm{I} 9 \mathrm{I} \mathbf{I}$ (Thousands of people)

\begin{tabular}{|c|c|c|c|c|}
\hline Decade & London & $\begin{array}{l}\text { Other } \\
\text { towns }\end{array}$ & $\begin{array}{l}\text { Colliery } \\
\text { districts }\end{array}$ & $\begin{array}{l}\text { Rural } \\
\text { areas }\end{array}$ \\
\hline$I 8_{4 I-r} 8_{5} I$ & +274 & +386 & $+8 z$ & -443 \\
\hline $185 I-I 86 I$ & +244 & 1272 & +103 & -743 \\
\hline $186 \mathrm{I}-\mathrm{I} 87 \mathrm{I}$ & +262 & $+27 \mathrm{I}$ & $+9 \mathrm{I}$ & -683 \\
\hline $187 I-I 88 I$ & +307 & +297 & +84 & -837 \\
\hline I $88 \mathrm{I}-\mathrm{T} 89 \mathrm{I}$ & +160 & $-3 I$ & +90 & -845 \\
\hline I 89I-I9OI & +226 & +294 & +85 & -660 \\
\hline I90I-I9I I & -232 & -89 & + II4 & -295 \\
\hline
\end{tabular}

From Deane \& Cole (1967); see also Cairncross (1953). 
The increase in urban population is shown in Table 3. The introduction of civil registration after 1837 allows us to record the great movement into the towns during the $1840^{\circ}$ s. Thus, by the middle of the century urban and rural population were equal in proportion and, by I90I, three-quarters of the people were town dwellers. After I $87^{\circ}$, the degree of urban density was already sufficient for individual towns to lose their identity in an urban sprawl, and Table 4 shows the extent to which present-day conurbations were already present in the nineteenth century.

Table 4. The development of conurbations, I87 I-I9I I

\begin{tabular}{|c|c|c|c|c|c|}
\hline \multicolumn{6}{|c|}{ (Millions of people) } \\
\hline Area & 1871 & I $88 \mathrm{I}$ & I 891 & 1901 & I9I \\
\hline Greater London & 3.9 & $4 \cdot 8$ & $5 \cdot 6$ & $6 \cdot 6$ & $7 \cdot 3$ \\
\hline South-east Lancashire & $I \cdot 4$ & $1 \cdot 7$ & I.9 & $2 \cdot I$ & $2 \cdot 3$ \\
\hline West Midlands & $1 \cdot 0$ & $I \cdot I$ & $r \cdot 3$ & $1 \cdot 5$ & $\mathrm{I} \cdot 6$ \\
\hline West Yorkshire & $\mathbf{I} \cdot \mathbf{I}$ & $1 \cdot 3$ & $I \cdot 4$ & $1 \cdot 5$ & I.6 \\
\hline Merseyside & 0.7 & 0.8 & 0.9 & $I \cdot 0$ & $I \cdot 2$ \\
\hline Tyneside & 0.3 & 0.4 & 0.6 & 0.7 & 0.8 \\
\hline Clydeside & - & -4 & - & $\mathrm{I} \cdot 3$ & 1.5 \\
\hline
\end{tabular}

From Mitchell \& Deane (r962),

\section{Economic factors affecting food habits}

From the end of the Napoleonic wars to the First World War, then, was a period of the growth of wealth, of industry, and of trade. But such growth in the economy does not automatically relate to a rise in the standard of living. At a time when the industrial revolution had achieved for Britain the position of being the foremost political and industrial power in the world, there was great poverty in the country. The incomes distribution policy determined the standard of living for the mass of the people. In the nineteenth century, incomes were very unequally distributed. For most of the century the so-called 'iron law of wages' based on the writings of the economist, David Ricardo, prevailed upon employers. Put simply, this held that the cost of subsistence determined wages, and therefore the difference in value between the amount produced by labour and the amount paid out in wages was profit. Hence it was the attempt to pay wages as low as possible which led to the existence in the nineteenth century of large groups of the population at subsistence level. Not only was this economic in consideration, but early in the century low wages appear to have been important as a form of social control. A popular book of the day (Townsend, $\mathrm{I}_{7} 86$ ) approved hunger as providing 'not only a peaceable, silent, unremitting pressure, but as the most natural motive to industry and labour, it calls forth the most powerful exertions'. Even at the end of the nineteenth century an American observer noted that British employers thought their workers' requirements were strictly limited and based their wage bargaining on the view 'that the workingman doe not need more than so many shillings a week' (Saul, ig6o).

The first economic factor affecting dietary patterns, therefore, was that consumer demand was a function of low incomes, and low purchasing power limited the amount of food eaten. The effect of this was clearly seen in the I 840 's where among the lower ranges of income, to quote a contemporary observer, "we find the animal 
food reduced to a small piece of bacon cut up with the potatoes; lower still, even this disappears, and there remain only bread, cheese, porridge, and potatoes, until on the lowest round of the ladder, among the Irish, potatoes form the sole food' (Engels, 1892). Secondly, and similar in effect, irregular employment-either seasonal or associated with trade cycles or even the changing structure of the industry -caused low purchasing power. The cotton spinner's life, wrote Carlyle, 'now in plethoric prosperity, anon extenuated into inanition and "short time", is of the nature of gambling; they live by it like gamblers, now in luxurious superfluity, now in starvation' (Carlyle, 1840). This uncertainty generated 'black mutinous discontent' among the working classes. Engels wrote in agreement: 'far more demoralising than his poverty in its influence upon the English working-man is the insecurity of his position, the necessity of living upon wages from hand to mouth, that in short which makes a proletarian of him' (Engels, I 892).

Thirdly, social conditions of life during the period of industrialization affected food habits by restricting demand for food. This was apparent where women's employment was of major importance to industry. It was particularly marked in textile areas, with the result that a working wife had little time to spend in meal preparation. In extreme cases, it even involved a reversal of roles within the family: 'In many cases the family is not wholly dissolved by the employment of the wife, but turned upside down. The wife supports the family, the husband sits at home, tends the children, sweeps the room and cooks. This case happens very frequently; in Manchester alone many hundred such men could be cited, condemned to domestic occupations' (Engels, I892). In addition, where dense areas of factory housing had developed, it was difficult for previous food habits based on the conditions of a rural society to survive. Most urban areas ceased to bake bread at home in the nineteenth century, and only traces of home brewing remained when Edward Smith made his investigations into diet in 1863 . Housing in the new urban areas seldom had adequate facilities for baking even if fuel was available cheaply, and much cookery was reduced to the limits of a frying pan and kettle. Even if these factors had not been sufficient, the nineteenth century Briton restricted his choice of food by prejudices and preferences about which we today know little: but it seems clear that attitudes of distrust towards fruit, vegetables, and milk remained strong until the very end of the nineteenth century (Cheadle, I902; Pavy, 1875; Holt, 1902).

To the economic and social historian, the period after 1825 is important as one in which the framework of modern industrial society was established and the decline of the previously predominant rural society came about. But to the nutritionist, it is important as a situation in which more and more people in the population became dependent on fewer and fewer people engaged in agriculture. The rapid growth of urban areas naturally threw a heavy strain on the existing supply system. The nineteenth century opened in a period during which food riots were a notable expression of discontent and, during the first half of the century, evidence of poor-quality food and widespread adulteration amply illustrates the near-breakdown in food supplies which occurred. Though prices of agricultural produce began to decline after the Napoleonic wars, the supply of food continued to depend on a high-cost transport 
system until the railways were developed. Perishability of animal foods meant that much was only available in dried or cured forms, so that grain products by virtue of their durability formed the basis of the diet. Table 5 shows Salaman's wheat and potato availability indices for the nineteenth century (Salaman, 1949). Per capita supplies of wheat declined from 1795 until the 1850 's, with the lowest point in 1846 , of $0.75 \mathrm{lb} / \mathrm{d}$. As a result, the potato became increasingly important in the diet. In the early nineteenth century it was undoubtedly regarded as a poor substitute for bread; it was known as the 'root of misery' and William Cobbett, who thought the right diet for Englishmen to be bread and beer, castigated it as 'the root of extreme unction'. According to Salaman's figures, consumption of potatoes remained fairly

Table 5. The supply of wheat and potatoes, I775-1914

(Daily consumption in $1 \mathrm{~b}$ per head)

\begin{tabular}{|c|c|c|}
\hline Year & Wheat* & Potatoes \\
\hline 1775 & $I \cdot 3$ & 0.25 \\
\hline 1795 & $I \cdot 36$ & 0.40 \\
\hline 1814 & $I \cdot 05$ & 0.47 \\
\hline 1838 & 0.90 & 0.62 \\
\hline $185 \mathrm{I}$ & 0.85 & 0.67 \\
\hline I 866 & $1 \cdot 03$ & 0.80 \\
\hline 1871 & 1.05 & 0.90 \\
\hline I $88 \mathrm{I}$ & 1.05 & 0.64 \\
\hline $189 \mathrm{I}$ & $1 \cdot 04$ & 0.65 \\
\hline I9OI & $1 \cdot 03$ & 0.58 \\
\hline 9 I I & $\mathrm{I} \cdot \mathrm{O}$ & 0.60 \\
\hline 114 & 1.01 & 0.53 \\
\hline
\end{tabular}

From Salaman (1949).

Salaman calculated the wheat supply for the United Kingdom, but deflated population figures to allow for lower wheat consumption in Scotland and Ireland. Potato supply was calculated for Fngland and Wales only.

*Average figures for the decade in which each year falls (except 1775 which is an individual value for that year).

high until the end of the nineteenth century. Salaman's view on this is interesting: he pointed out that only when the general rise in wages which had begun in the I 860's was sufficient for the labourer to buy four quartern loaves a day did the demand for potatoes begin to fall off and that, for the agricultural labourer at least, this point was not reached until the early twentieth century (Salaman, 1949).

Even if this was rather an ad hoc method of assessing the situation, it fits what is known of the circumstances. Although grain imports begain to mount through the r 860's and I870's and livestock traffic reached a peak in the r 880's, the real benefits of the improvements in international transport and the expansion of overseas agriculture were not reached until the $1890^{\circ}$ 's. By that time refrigeration techniques had reached a sufficiently advanced stage for large imports of butter and meat to reach Britain. In effect, preservation techniques and the development of food technology were relevant factors in the supply situation only at the very end of the century. 


\section{Some evidence of food consumption}

The effect of changes in supply and demand on consumption of food cannot be assessed with any accuracy in the absence of adequate information. Rather than attempt to construct a series of per capita estimates of food consumption based on statistics of trade and output, it is, perhaps, more interesting to compare the results of analysing evidence obtained from family budgets. The weekly per capita consumption of food is shown in Table 6. The figures for ${ }^{8} 8_{4} \mathrm{I}$ are taken from William Neild's survey of families in Manchester and Dukinfield (McKenzie, I 962) and for I863 from Edward Smith's large-scale survey of families of low-paid workers (Oddy $\&$ Yudkin, 1969 ). The remaining columns are averages based on a number of surveys carried out between $1887-1901$, and 1902-1913, and include the remarkable studies of Booth \& Rowntree. The analysis of these diets was based on a process of computerassisted dietary analysis designed by Mr D. S. Miller and Miss Pamela Mumford, Department of Nutrition, Queen Elizabeth College.

Table 6. Weekly food consumption, $184^{1-191}$, from family budget evidence

\begin{tabular}{|c|c|c|c|c|}
\hline Food & 1841 & I 863 & $1887-190 \mathrm{I}$ & I $902-1913$ \\
\hline Bread (lb) & $5 \cdot 4$ & $5 \cdot 4$ & $6 \cdot 5$ & $6 \cdot 7$ \\
\hline Potatoes (lb) & $5 \cdot 2$ & $2 \cdot 4$ & $x \cdot 6$ & $2 \cdot 9$ \\
\hline Milk (pints) & $I \cdot 6$ & 0.75 & $x \cdot 4$ & $I=7$ \\
\hline Sugar (lb) & $0-4$ & 0.5 & 0.9 & $I \cdot 0$ \\
\hline Meat (lb) & $I \cdot 0$ & 0.8 & $I \cdot 4$ & $I \cdot 3$ \\
\hline Fats (lb) & 0.4 & 0.3 & 0.5 & 0.48 \\
\hline
\end{tabular}

Although these columns should not be closely compared as they are in no sense to be regarded as statistical samples, certain generalizations may be made about the diets of the working classes during the process of urbanization in England.

Bread and potatoes were the staple foods in working class households, while the intake of meat, fats and milk was low. Some increase in milk consumption may have taken place between the I880's and 1914 (Cohen, 1936) as improved transport of milk to towns developed, though consumption in Britain probably lagged behind that of other highly developed economies. Sugar is the one food which one must assume was consumed in ever-increasing quantities throughout the century.

The daily nutrient intake provided by these diets is shown in Table 7 . This indicates that throughout the century carbohydrates were the main source of calories and that protein and fat intakes were low. The total calorific value of these diets is barely adequate by present standards, and positively inadequate when taking into

'Table 7. Daily nutrient intake, $\mathrm{I}_{4} \mathrm{I}^{\mathrm{I}-\mathrm{r} 9 \mathrm{I} 3}$, from family budget evidence

$\begin{array}{lcccc} & 184 \mathrm{r} & 1863 & 1887-\mathrm{r} 901 & 1902-1913 \\ \text { Encrgy value (kcal) } & 2300 & 2188 & 2077 & 2431 \\ \text { Protein (g) } & 65 & 55 & 58 & 67 \\ \text { Fat (g) } & & 53 & 57 & 73 \\ \text { Carbohydrate }(\mathrm{g}) & & 370 & 330 & 380 \\ \text { Iron (mg) } & 15 & 12.5 & 10.0 & 12.2 \\ \text { Calcium (g) } & & 0.36 & 0.3 & 0.47\end{array}$


account the less sedentary nature of ninetecnth century life and work. Iron intake was similar to present-day levels, while calcium intake was very much lower.

Finally, Table 8 shows urban and rural diets in the middle and at the end of the nineteenth century. Smith's 'indoor' category in 1863 included both workers in a completely urban environment, and some in industrialized villages whose way of life was certainly that of urban workers.

Table 8. Comparison between urban and rural food consumption from family budget evidence

Foods:
Bread (lb/week)
Potatoes (lb/week)
Milk (pints/week)
Sugar (lb/week)
Meat $(\mathrm{lb} /$ week)
Fats $(\mathrm{lb} /$ week)
Nutrients:
Energy value $(\mathrm{kcal} / \mathrm{d})$
Protein $(\mathrm{g} / \mathrm{d})$
Fat $(\mathrm{g} / \mathrm{d})$
Carbohydrate $(\mathrm{g} / \mathrm{d})$
Iron $(\mathrm{mg} / \mathrm{d})$
Calcium $(\mathrm{g} / \mathrm{d})$

\begin{tabular}{cccc} 
& & \multicolumn{2}{c}{ I902-I3 } \\
Indoor & Rural & Urban & Rural \\
& & & \\
5.4 & $6 \cdot 9$ & $6 \cdot 7$ & 5.7 \\
2.4 & 4.4 & 2.9 & 4.4 \\
0.75 & $1 \cdot 6$ & $1 \cdot 7$ & $2 \cdot 0$ \\
0.5 & 0.4 & 0.9 & 0.8 \\
0.8 & 0.9 & $1 \cdot 3$ & 0.8 \\
0.3 & 0.3 & 0.5 & 0.3 \\
& & & \\
2190 & 2760 & 2431 & 2172 \\
55 & 70 & 67 & 56 \\
53 & 54 & 73 & 53 \\
370 & 460 & 380 & 370 \\
12.5 & 15.9 & 12.2 & $11 \cdot 0$ \\
0.36 & 0.48 & 0.47 & $0.4 \mathrm{I}$
\end{tabular}

With the exception of sugar, rural families in the I 860 's ate more of all the main foods than urban families and, as a result, apart from fat, their nutrient intake was significantly higher than that of urban families. By the early twentieth century the situation was reversed. Some improvement in urban food supplies of meat, milk and butter is reflected by increases in these foods in the urban diets, but rural workers had not benefited in the same way. 'Their wages had not risen as had those of urban workers, and this is shown by a lower consumption of bread and other sources of carbohydrates in the diet. As a result, the energy value of the rural diets may well have been lower by the end of the century than it had been in the I 860 's.

\section{Conclusion}

Many facets of life were affected during the period of transition from a predominantly rural to an industrial and urban society. A deterioration in the diet of the working classes seems probable in the early nineteenth century and although food supplies in general improved as the century progressed, the nutritional status of the working class showed comparatively little change.

Carbohydrate foods, such as bread and potatoes, supplied two-thirds or more of the calories, and consumption of meat, fat and milk remained low. Fruit, vegetables and eggs contributed little to the diet, which was therefore unavoidably monotonous. From the emphasis placed by Victorians on Sunday dinner, it may be assumed that most of the meat and any vegetables were eaten at that meal, with the result that 
during the week, in Booth's words: 'a good deal of bread is eaten and tea drunk especially by the women and children'.

Without detailed knowledge of distribution of food within the family or of workloads in industry, the adequacy of the diet is difficult to assess. However, the concern exhibited in the late nineteenth century for social problems involving the standard of living requires some comment.

The improvement in wages, the reduction in hours of work in those industries in which labour was well-organized, and the fall in the price of foodstuffs from the I 880 's, all point to an improvement in the standard of living. On the other hand, there is some evidence of greater intensity of work per hour being introduced (Merttens, $1893^{-4}$ ), and of the health of urban populations being still unsatisfactory, despite marked changes in public health administration. It must be remembered that infant mortality rates were still as high in 1900 as they were when civil registration began in 1837 , while tuberculosis, rickets, dental caries and anaemia were all endemic diseases in urban areas of Britain at the outbreak of war in 1914.

\section{REFERENCES}

Cairncross A. K. (1953). Home and Foreign Investment 1870-1913. Cambridge: University Press. Carlyle, T. (1840). Chartism p. 34. London: James Fraser.

Cheadle, W. B. (1902). Artificial Feeding and Food Disorders of Infants p. 46. London: Smith, Elder \& Co.

Cipolla, C. M. (1965). In Population in History: Essays in Historical Demography p. 574. [D. V. Glass and D. E. C. Eversley, editors]. London: Edward Arnold.

Cohen, R. L. (1936). The History of Milk Prices p. 27. Oxford: Agricultural Economics Research Institute.

Deane, P. \& Cole, W. A. (1967). British Economic Growth, I688-1959 and ed. Cambridge: University Press.

Engels, F. (1892). The Condition of the Working-Class in England in 1844 . London: Swan Sonnenschein \& $\mathrm{Co}$.

Hobbes, T. (165I). Leviathan p. 62. London: Andrew Crooke.

Hoffman, W. G. (1955). British Industry, r700-1950. Oxford: Blackwell.

Holt, L. E. (1902). The Diseases of Infancy and Childhood p. 213. New York: D. Appleton \& Co.

McKenzie, J. C. ( $\left(\mathrm{g}_{2}\right)$. The Composition and Nutritional Value of Diets in Manchester and Dukinfield in 1841 . Trans. Lancs, and Cheshire Antiq. Soc. 72.

Merttens, I:. (1893-4). Trans. Manchr statist. Soc.

Mitchell, B. R. \& Deane, P. (1962). Abstract of British Historical Statistics. Cambridge: University Press.

Oddy, D. J. \& Yudkin, J. (1969). Proc. Nutr. Soc. 28, I3A.

Pavy, F. W. (1875). A Treatise on Food and Dietetics p. 283. London: J. \& A. Churchill.

Salaman, R. N. (1949). The History and Social Influence of the Potato. Cambridge: University Press.

Saul, S. B. (1960). The American Impact upon British Industry. British History Vol. 3, no. I, p. 27.

Townsend, J. (г786). A Dissertation on the Poor Laws (by a Well-zvisher of Mankind) p. 14. London: C. Dilly.

\section{The growth and nature of urban areas in developing countries}

By G. L. Burke, The College of Estate Management, St Alban's Grove, London, W8

In thinking how to make a start on these global terms of reference I recalled some observations of Pierre Bertaux (1968) at Washington in 1967 : 'whom and what do we mean by man? ... normally the "Western white civilised male adult"- - who is, in fact, 29 (I) $\mathrm{J} \mathrm{I}$ 